\title{
Oviposition of Naupactus cervinus (Boheman) and Naupactus xanthographus (Germar) (Coleoptera: Curculionidae) under laboratory conditions on orange fruit
}

\author{
Natalia Olivares ${ }^{1 *}$, Nathalie Morales ${ }^{2}$, Paola Luppichini ${ }^{3}$, and Eugenio López ${ }^{4}$
}

Fuller's rose weevil, Naupactus cervinus (= Asynonychus = Pantomorus cervinus) (Boheman), is a cosmopolitan pest that currently represents a serious quarantine problem for the Chilean citrus industry due to its similarity at the egg stage with the quarantine pest Naupactus xanthographus (Germar). The objective of this research was to study the biological aspects associated with $N$. cervinus and $N$. xanthographus oviposition habits under laboratory conditions on orange (Citrus sinensis [L.] Osbeck) fruit. Adult $N$. cervinus and N. xanthographus were collected from the field to carry out the research. Results show that $N$. cervinus fecundity was higher than $N$. xanthographus by more than $70 \%$, but egg viability was lower. It was recorded that $71.90 \%$ N. cervinus ovipositions were under the calyx. Likewise, $52.46 \%$ N. xanthographus ovipositions occurred on leaves and $40.98 \%$ on the surface of the plastic cage. In the present study, only N. cervinus lays egg masses under the calyx of citrus fruit.

Key words: Citrus sinensis, egg masses, Fuller's rose weevil, oviposition, Naupactus.

\section{INTRODUCTION}

The Naupactini (Curculionidae: Entiminae) tribe consists of approximately 65 genera (Alonso-Zarazaga and Lyal, 1999) with over 500 species mainly distributed in Central and South America (Wibmer and O'Brien, 1986); it is one of the most diverse tribes and is highly important for phytosanitary reasons (Lanteri, 1994; Lanteri et al., 2002a). Within this tribe, the main curculionidae pests found in Chilean citrus trees are Naupactus (= Asynonychus = Pantomorus cervinus) (Boheman) and Naupactus xanthographus (Germar) (Ripa and Luppichini, 2008; Olivares et al., 2014).

Naupactus cervinus was first described in 1840 by Boheman, but its taxonomic history is mixed because it has had several changes in its generic designation and species. Among those changes are the following: Asynonychus godmani (Crotch), 1867; Aramigus fulleri (Horn), 1876; Naupactus simplex (Pascoe), 1881; Pantomorus olindae

${ }^{1}$ Instituto de Investigaciones Agropecuarias, INIA La Cruz, Casilla 3, Quillota, Chile. ${ }^{*}$ Corresponding author (nolivare@inia.cl).

${ }^{2}$ Pontificia Universidad Católica de Valparaíso, Instituto de Biología, Casilla 4059, Valparaíso, Chile.

${ }^{3}$ Centro de Entomología Aplicada Ltda., Biocea, Casilla 59, La Cruz, Chile.

${ }^{4}$ Pontificia Universidad Católica de Valparaíso, Facultad de Agronomía, Casilla 4-d, Quillota, Chile.

Received: 2 May 2014.

Accepted: 8 August 2014.

doi:10.4067/S0718-58392014000400019
(Perkins), 1900; P. cervinus (Boheman), P. godmanni (Crotch), Asynonychus cervinus (Boheman), Hustache 1947; Pantomorus cervinus (Boheman), and Kuschel 1949 (Chadwick, 1965; Woodruff and Bullock, 1979; Alonso-Zarazaga and Lyal, 1999). It subsequently went back to its first taxonomic designation (AlonsoZarazaga and Lyal, 1999). The taxonomic history of $N$. xanthographus is simpler. It was described by Germar in 1824, who had previously classified it as Leptocerus xanthographus (Elgueta and Marvaldi, 2006).

Both Naupactus cervinus and N. xanthographus are polyphagous species. Adult $N$. cervinus feed mainly on roses and citrus fruit in addition to a great variety of plants such as lucerne, raspberry (Rubus idaeus L.), strawberry, blueberry (Vaccinium corymbosum L.), peach tree (Prunus persica [L.] Batsch), apple tree, and avocado tree (Persea americana Mill.) (Elgueta, 1993; Ripa and Rodríguez, 1999; Del Rio et al., 2010). It damages Citrus spp. (Rutaceae) in Brazil (Lanteri et al., 2002b) and ornamental plants in the USA (Lanteri et al., 2002a). In Chile, N. xanthographus is largely associated with grapevine (Vitis vinifera L.), custard apple (Annona cherimola Mill.), plum (Prunus domestica L.), peach, cherry (Prunus cerasus L.), walnut (Juglans regia L.), pear (Pyrus communis L.), kiwifruit (Actinidia deliciosa [A. Chev.] C.F. Liang \& A.R. Ferguson), orange (Citrus sinensis [L.] Osbeck), lemon (Citrus limon [L.] Burm. f.), avocado, blueberry, persimmon (Diospyros kaki Thunb.), and raspberry, as well as other vegetable crops such as beetroot (Beta vulgaris L.), potatoes (Solanum 
tuberosum L.), and bean (Phaseolus vulgaris L.) (Ripa and Luppichini, 2010). Moreover, it is part of the lucerne curculionidae complex in Argentina and it was frequently found in soybean crops in recent years (Lanteri, 1994; Lanteri et al., 2002a).

Although the Naupactini tribe has many morphofunctional similarities, the species group has distinct biological characteristics, especially in their type of oviposition (Lanteri and Del Rio, 2008). Lanteri et al. (2002b) classified the Naupactini tribe into two categories: insects that lay their eggs in masses attached to the crevices and folds of leaves and insects that lay their eggs on the soil.

The Naupactini tribe prefers narrow grooves that are wide enough for females to introduce their distended ovipositor and not too far so as to expose the eggs to desiccation or natural enemies. It is also mentioned that oviposition in fruit is related to insect size where those that are larger than $2 \mathrm{~cm}$ tend not to lay their eggs on the fruit (Guedes and Parra, 2004).

In Chile, more than $80 \%$ of pest-related rejections in citrus production -mainly oranges-are due to the presence of curculionidae egg masses under the calyx (SAG, 2013). However, there is no evidence indicating that $N$. xanthographus lays eggs under the orange calyx; this is done only by the female species of $N$. cervinus.

Therefore, the objective of this research was to study the biological aspects associated with the oviposition habits of the $N$. xanthographus and $N$. cervinus species under laboratory conditions on orange fruit.

\section{MATERIALS AND METHODS}

\section{Biological material}

Adult $N$. cervinus and N. xanthographus were collected from the field in January 2013. Collections were conducted in citrus orchards located in the two municipalities of Ovalle (30³5.370' S, $71^{\circ} 22.423^{\prime} \mathrm{W}$ ) and Pan de Azúcar $\left(30^{\circ} 06.753^{\prime} \mathrm{S}, 71^{\circ} 12.997^{\prime} \mathrm{W}\right)$. January is the month when adult emergence of $N$. cervinus (Olivares et al., 2014) and N. xanthographus begins (Ripa, 1992).

Biological material was collected by the Instituto de Investigaciones Agropecuarias (INIA) staff. Adults of both species were collected by the branch banging technique (Ripa and Luppichini, 2008; Olivares et al., 2014).

\section{Fecundity and fertility of $N$. cervinus and $N$.} xanthographus

Trials were carried out in the laboratory at $20 \pm 4{ }^{\circ} \mathrm{C}, 57$ $\pm 10 \% \mathrm{RH}$, and $14: 10 \mathrm{~h}$ photoperiod. Each experimental unit was a plastic cage $(25 \times 15 \times 11 \mathrm{~cm})$ adapted for adult insect rearing. A female $N$. cervinus was placed inside this cage with one orange fruit (Citrus sinensis [L.] Osbeck) 'Navel Late' (Guedes and Parra, 2004). For the $N$. xanthographus, a female and a male with one fruit were placed in each experimental unit. Three orange leaves were added as substrate feed in each experimental unit. For each weevil species, 15 replicates were done with newly emerged females.

Each experimental unit was evaluated daily. The presence of egg masses on different substrates was recorded. Eggs were removed and counted under a stereomicroscope (Carl Zeiss, Oberkochen, Germany). The oviposition date and number of eggs were recorded. Eggs were then placed in plastic 5-cm diameter containers on moistened filter paper to determine the mean number of eggs per female per day. These containers were kept in the laboratory and monitored to determine the number of hatched larvae.

The number of eggs laid by every female in its lifetime was added to calculate total fecundity. Fertility was calculated by adding the number of hatched larvae in relation to the total number of eggs laid in its lifetime.

\section{Oviposition substrate preference of $N$. cervinus and $N$. xanthographus}

Each experimental unit of $N$. cervinus corresponded to a cage $(25 \times 15 \times 11 \mathrm{~cm})$ adapted for adult insect rearing with one female and containing one fruit and three orange 'Navel Late' leaves as oviposition substrate. For $N$. xanthographus, a couple was placed in the oviposition substrates described above. Vine leaves were used as food for this species (V. vinifera) (Guedes and Parra, 2004).

Experimental units were checked on a daily basis to record the presence or absence of $N$. cervinus and $N$. xanthographus eggs masses under the calyx, on the fruit surface, leaves, and rearing cages. When an egg mass was found on a fruit, it was replaced with another. If eggs were not detected, fruit were replaced every $2 \mathrm{~d}$ to maintain them hydrated and turgid. Leaves were replaced daily and sprayed with water to keep them hydrated. For each Naupactus species, 15 replicates were done.

\section{Statistical analysis}

The number of ovipositions per female, number of eggs per mass, fecundity, fertility, and oviposition substrates were analyzed by ANOVA. Means were separated by the least significant difference (SAS Institute, 2009). Data that did not show a normal distribution were transformed by $\sqrt{(x+0.5)}$ (Little and Hills, 1976).

\section{RESULTS AND DISCUSSION}

\section{Fecundity and fertility of $N$. cervinus and $N$.} xanthographus

Naupactus cervinus produced a mean of 25.35 eggs per mass with 9.26 masses per female (Table 1). For $N$. xanthographus, the mean of eggs per mass was 44.71 eggs with 4.13 masses per female. Coats and McCoy (1990) indicate that the mean of eggs per mass of $N$. cervinus is 38.5 and the mean of ovipositions is 1.8 for a 2 -wk period. 
Table 1. Oviposition parameters of Naupactus cervinus and Naupactus xanthographus.

\begin{tabular}{|c|c|c|c|c|}
\hline Species & Masses per female & Eggs per mass* & $\begin{array}{c}\text { Fecundity } \\
\text { (eggs per female) }\end{array}$ & $\begin{array}{c}\text { Fertility } \\
(\% \text { hatched larvae })\end{array}$ \\
\hline N. cervinus & $9.26 \pm 2.89 \mathrm{a}$ & $25.35 \pm 3.29 b$ & $235.47 \pm 82.85 a$ & $33.92 \pm 10.42 c$ \\
\hline N. xanthographus & $4.13 \pm 1.72 b$ & $44.71 \pm 9.12 \mathrm{a}$ & $180.0 \pm 64.54 \mathrm{ab}$ & $53.92 \pm 19.03 b$ \\
\hline
\end{tabular}

Different letters indicate a significant difference between treatments according to the LSD test ( $\mathrm{p} \leq 0.05$ ). Data are presented as mean \pm standard deviation.

*Eggs were collected daily from each experimental unit.

McCoy (1994) shows that the number of $N$. cervinus eggs per mass varies between 70 and 100 eggs and with a total of 300 . Guedes et al. (2007) reported that $N$. cervinus lays 120.9 eggs per female with a mean of 4.2 ovipositions and a mean of 28.7 eggs per mass.

Additionally, Guedes et al. (2007) indicate that $N$. cervinus compared with $N$. versatilis exhibits a smaller body size, which would explain in part its reduced oviposition ability.

The highest fertility corresponded to $N$.xanthographus (53.92\%) and then N. cervinus (33.92\% hatched larvae, viable eggs). Guedes and Parra (2007) obtained viability at the egg stage at different temperatures and registered a mean of $59.4 \%$ for $N$. cervinus. As temperature increased, egg viability was higher, which led to $79.6 \%$ eggs hatching at $32{ }^{\circ} \mathrm{C}$. The same authors studied the fertility of $N$. versalis, another species of the Naupactini tribe, and recorded mean fertility of $56.1 \%$.

The same study indicates that death can occur during oviposition due to the presence of fungus (4\%) and dehydration (3\%). Gallego et al. (2012) studied feeding and oviposition behavior in Compsus viridivittatus and registered $94 \%$ viability, whereas it was only $10 \%$ in $C$. latifolia; this shows that there is a significant host effect.

Total fertility was 235.4 eggs for each $N$. cervinus female and 180 eggs for the $N$. xanthographus female. These results differ from those reported by Ripa (1983), who indicates that each $N$. xanthographus female can oviposit 600 eggs on the average under laboratory conditions. East (1977) reported a variation in the mean number of eggs per female in N. leucoloma and associated fertility with the host.

Lanteri (2010) indicates that the species of parthenogenetic Curculionidae would double their fertility with respect to those that produce balanced sex offspring. From these results, it can be observed that $N$. cervinus species fecundity was higher than for $N$. xanthographus by more than $70 \%$, but egg viability was lower.
Oviposition site preference of $N$. cervinus and $N$. xanthographus

It was observed that $N$. cervinus oviposition was $71.94 \%$ under the calyx, $13.66 \%$ on leaves, and $14.38 \%$ on the rearing cage surface. In $N$. xanthographus, results show that $51.6 \%$ of oviposition occurs on leaves, $6.44 \%$ on the fruit surface, and $40.1 \%$ on the cage surface (Table 2 ). Then it was observed that $N$. cervinus oviposition was protected under the fruit calyx; N. xanthographus egg masses were laid on an unprotected area of the fruit surface.

Results of oviposition preference in this study are similar to those reported by Barattini (2008), who states that the first oviposition preference of $N$. cervinus is under the calyx of lemon fruit (88\%) and dry leaves (12\%) under field conditions in a lemon orchard. In addition, authors that collected egg masses in the field from citrus orchards observed that $100 \%$ of the eggs under fruit orange sepals corresponded to $N$. cervinus.

Guedes and Parra (2004) determined that $N$. cervinus and Parapantomorus fluctuosus (Boheman) oviposition occurred only on the fruit by using free choice substrates that provided leaves, plastic, and fruit. Moreover, oviposition was observed on the plastic, but not on leaves when there was no choice of substrate.

Coats and McCoy (1990) note that $83.2 \%$ N. cervinus eggs are laid on the fruit, $16 \%$ on leaves, and $0.8 \%$ on branches. This preference may be influenced by the population density of this pest because $60 \%$ of the eggs were found at lower densities on the fruit, whereas the percentage rises to $90 \%$ at higher densities. McCoy (1994) indicates that females lay $80 \%$ of their eggs under the citrus fruit calyx. Maher and Logan (2004) note that $45 \%$ oviposition occurred on the experimental container nets, $41 \%$ on blocks with polyethylene bands, $6.3 \%$ on foliage, and the remaining $8 \%$ is divided on different sites. The results of the present study verify that $N$. cervinus lays egg masses mostly under the citrus fruit calyx.

Table 2. Percentage oviposition of Naupactus cervinus and Naupactus xanthographus egg masses on different substrates.

\begin{tabular}{lccc}
\hline & & \multicolumn{2}{c}{ Oviposition substrates } \\
\cline { 3 - 4 } Species & Calyx & Leaves & Fruit surface \\
\hline N. cervinus & $71.94 \pm 1.65 \mathrm{aA}$ & $13.67 \pm 0.71 \mathrm{bB}$ & $0 \mathrm{aC}$ \\
N. xanthographus & $0 \mathrm{cB}$ & $52.46 \pm 1.73 \mathrm{aA}$ & $6.56 \pm 0.75 \mathrm{bB}$ \\
\hline
\end{tabular}

Different vertical lowercase letters indicate a significant difference between species and horizontal uppercase letters indicate a significant difference between substrates according to the LSD test $(\mathrm{p} \leq 0.05)$. Data are presented as the percentage of egg masses \pm standard deviation. 


\section{CONCLUSIONS}

Under laboratory conditions, oviposition habits of the Naupactus xanthographus and N. cervinus species were different. The most important oviposition substrate preference of $N$. cervinus corresponded to the calyx of the citrus fruit. Female N. xanthographus did not lay egg masses under the calyx. The results of this study add to the knowledge of oviposition behavior in the $N$. xanthographus species. This information will prevent the rejection of Chilean citrus fruit at export control points due to the similarity of $N$.xanthographus and $N$. cervinus eggs.

\section{ACKNOWLEDGEMENTS}

We wish to acknowledge funding by the INNOVA-Chile project "Development of novel technologies in IPM program in citrus", grant \#07CN13PAT-04.

\section{LITERATURE CITED}

Alonso-Zarazaga, M.A., and C.H.C. Lyal. 1999. A world catalogue of families and genera of Curculionoidea (Insecta: Coleoptera) (excepting Scolytidae and Platypodidae). 316 p. Entomopraxis, Barcelona, Spain.

Barattini, P. 2008. Estudio de aspectos biológicos del capachito de los frutales Pantomorus cervinus (Boheman) (Coleoptera: Curculionidae) en relación a parámetros naturales. 19 p. Tesis de Biólogo. Pontificia Universidad Católica de Valparaíso, Facultad de Ciencias, Valparaíso, Chile.

Chadwick, C.E. 1965. A checklist of the Brachyderinae (Col., Curculionidae) occurring in Australia. Journal of the Entomological Society of Australia 2:21-34.

Coats, S.A., and C.W. McCoy. 1990. Fuller rose beetle (Coleoptera: Curculionidae) ovipositional preference on Florida citrus. Journal of Economic Entomology 83:860-865.

Del Rio, M.G., P. Klasmer, y A.A. Lanteri. 2010. Gorgojos (Coleoptera: Curculionidae) perjudiciales para "frutos rojos" en la Argentina. Revista Sociedad Entomológica de Argentina 69:101110 .

East, R. 1977. Effects of pasture and forage crop species on longevity, fecundity, and oviposition rate of adult white-fringed weevils Graphognathus leucoloma (Boheman). New Zealand Journal of Experimental Agriculture 5:177-181.

Elgueta, M. 1993. Las especies de Curculionidae (Insecta: Coleoptera) de interés agrícola en Chile. Publicación Ocasional 48.79 p. Museo Nacional de Historia Natural, Santiago, Chile.

Elgueta, M., y A.E. Marvaldi. 2006. Lista sistemática de las especies de Curculionidae (Insecta: Coleoptera) presentes en Chile, con su sinonímia. Boletín del Museo Nacional de Historia Natural, Chile 55:113-153.

Gallego, C., S. Jeisson, A. Caicedo, A. Carabali, y J.E. Muñoz. 2012. Comportamiento alimenticio y de oviposición de Compsusviridivittatus (Coleoptera: Curculionidae) en especies de cítricos. Rev. Colombiana de Entomología [Online] 38:191-195.

Guedes, J.C., e J.R. Parra. 2004. Oviposição dos curculionídeosdas-raízes dos citros (Coleoptera: Curculionidae). Ciência Rural, Santa Maria 34:673-678.

Guedes, J.C., e J.R. Parra. 2007. Aspectos biologicos do periodo embrionario dos curculionideos-das-raizes dos citros. Neotropical Entomology 36:192-196.
Guedes, J.C., J.R. Parra, e R.A. Fiorin. 2007. Aspectos biologicos da fase adulta dos curculionideos-das-raízes dos citros. Ciência Rural, Santa Maria 37:304-307.

Lanteri, A.A. 1994. Identificación de las especies. Bases para el control integrado de los gorgojos de la alfalfa. p. 3-40. De la Campana Ediciones, La Plata, Argentina.

Lanteri, A.A. 2010. La partenogénesis en el reino animal. Ciencia Hoy 20:21-28.

Lanteri, A.A., y M.G. del Río. 2008. Caracteres genitales de la hembra en la clasificación y filogenia de la tribu Naupactini (Coleoptera: Curculionidae). 159-176 p. In Llorente Bousquets, J., y A.A. Lanteri (eds.) Contribuciones taxonómicas en órdenes de insectos hiperdiversos. UNAM-RIBES-CYTED, México, D.F.

Lanteri, A.A., J.C. Guedes, and J.R.P. Parra. 2002b. Weevil injurious for roots of citrus in São Paulo State, Brazil. Neotropical Entomology 31:561-569.

Lanteri, A.A., E. Marvaldi, y S.M. Suárez. 2002a. Gorgojos de la Argentina y sus plantas huéspedes. Tomo I: Apionidae y Curculionidae. Publicación Especial de la Sociedad Entomológica Argentina 1:98.

Little, T.M., y F.J. Hills. 1976. Métodos estadísticos para la investigación en la agricultura. 136 p. Editorial Trillas, México D.F.

Maher, B.J., and D.P. Logan. 2004. Comparison of host plant preferences, fecundity and longevity for diet-reared and fieldcollected Fuller's rose weevil. New Zealand Plant Protection 57:183-190.

McCoy, C.W. 1994. Citrus root weevils: Biology and current IPM strategies in Florida. 145-170 p. In Gravena, S., and L.C. Donadio (eds.) Citrus: Integrated management of insect and mite pests: A world overview. FUNEP, Jaboticabal, São Paulo, Brazil.

Olivares, N., P. Luppichini, y C. Volosky (eds.) 2014. Plagas de los cítricos: reconocimiento y manejo. Boletín INIA No 282.120 p. Instituto de Investigaciones Agropecuarias INIA, La Cruz, Chile.

Ripa, R. 1983. Naupactus xantographus, el burrito de los frutales y vides. Biología y control. Boletín Divulgativo $\mathrm{N}^{\circ}$ 98. Instituto de Investigaciones Agropecuarias INIA, La Cruz, Chile.

Ripa, R. 1992. Burrito de los frutales Naupactus xanthographus. Boletín Técnico $\mathrm{N}^{\circ}$ 192. p. 9-23. Instituto de Investigaciones Agropecuarias INIA, La Cruz, Chile.

Ripa, R., y P. Luppichini. 2008. Capachito de los frutales. p. 158-162. In Ripa, R., y P. Larral (eds.) Manejo de plagas en paltos y cítricos. Colección de Libros INIA $\mathrm{N}^{\circ} 23$. Instituto de Investigaciones Agropecuarias INIA, Santiago, Chile.

Ripa, R., y P. Luppichini. 2010. Manejo de plagas de la vid. Colección libros INIA N ${ }^{\circ} 26.145$ p. Instituto de Investigaciones Agropecuarias INIA, Santiago, Chile.

Ripa, R., y F. Rodríguez. 1999. Plagas de cítricos, sus enemigos naturales y manejo. Colección Libros INIA N ${ }^{\circ} 3.151$ p. Instituto de Investigaciones Agropecuarias INIA, Santiago, Chile.

SAG. 2013. Servicio Agrícola y Ganadero (SAG), Santiago, Chile. Available at http://www.sag.cl/ (accessed February 2014).

SAS Institute. 2009. SAS system for Windows 2000, version 9.1. SAS Institute, Cary, North Carolina, USA.

Wibmer, G., and C.W. O'Brien. 1986. Annotated checklist of the weevils (Curculionidae sensulato) of South America (Coleoptera: Curculionidae). Memoirs of the American Entomological Institute nr 39. 563 p. American Entomological Institute, Gainesville, Florida, USA.

Woodruff, R.E., and R.C. Bullock. 1979. Fuller's Rose weevil Pantomorus cervinus (Boheman), in Florida (Coleoptera: Curculionidae). Entomology Circular 207.4 p. Florida Department of Agriculture and Consumer Services, Division Plant Industry, Florida Capitol, Tallahassee, Florida. 